\title{
Pengaruh Konsentrasi Pupuk Organik Cair Dari Eceng Gondok (Eichhornia crassipes) Yang Berbeda Terhadap Pertumbuhan Dan Kandungan Protein Chlorella vulgaris
}

\author{
[The Effect of Water Hyacinth (Eichhornia crassipes) Liquid Organic Fertilizer \\ Concentration on The Growth and Protein Content of Chlorella vulgaris] \\ Yulina $^{1}$, Wa Iba1, Muhaimin Hamzah \\ ${ }^{1}$ Program Studi Budidaya Perairan, Faluktas Perikanan dan Ilmu Kelautan Universitas Halu Oleo \\ J1. HAE Mokodompit Kampus Bumi Tridharma Anduonohu Kendari, Indonesia 93232 \\ Email korespondensi : yulinalina96@gmail.com
}

\begin{abstract}
ABSTRAK
Penelitian ini bertujuan untuk mengetahui pengaruh konsentrasi pupuk organik cair dari eceng gondok (POC EG) terhadap pertumbuhan sel dan kandungan protein $C$. vulgaris. Penelitian ini menggunakan Rancangan Acak Lengkap yang terdiri dari 5 perlakuan dan 3 kali ulangan. Volume media kultur $300 \mathrm{ml}$ pada masing-masing media f/2, 5\%, 10\%, 15\% dan 20\% POC EG dengan stok awal $10 \times 10^{4} \mathrm{sel} / \mathrm{ml} \mathrm{C}$. vulgaris. Parameter yang diamati dalam penelitian ini yaitu kepadatan sel, laju pembelahan sel, $S G R$, yield dan kandungan protein $C$. vulgaris. Hasil penelitian ini kepadatan sel tertinggi $C$. vulgaris pada hari ke-4 didapatkan pada perlakuan 15\% POC EG yaitu $10,62 \times 10^{5} \mathrm{sel} / \mathrm{ml}$ bila dibandingkan dengan media f/2 yaitu 4,66x $10^{5}$ $\mathrm{sel} / \mathrm{ml}$ dengan nilai statistik berbeda nyata $(\mathrm{P}<0,001)$. SGR tertinggi pada perlakuan $15 \%$ POC EG yaitu 0,95 sel/hari bila dibandingkan dengan media $\mathrm{f} / 2$ yaitu $0,20 \mathrm{sel} / \mathrm{hari}$ nilai statistik berbeda nyata $(\mathrm{P}<0,001)$. Laju pembelahan sel per hari tertinggi pada perlakuan 15\% POC EG yaitu 1,37 kali bila dibandingkan dengan media f/2 yaitu 0,29 kali nilai statistik berbeda nyata $(\mathrm{P}<0,001)$. Pada hari ke-4 yield tertinggi $C$. vulgaris didapatkan pada perlakuan $15 \%$ POC EG yaitu $5,81 \times 10^{5} \mathrm{sel} / \mathrm{ml}$ bila dibandingkan dengan media $\mathrm{f} / 2$ yaitu $3,33 \times 10^{5} \mathrm{sel} / \mathrm{ml}$ nilai statistik berbeda nyata $(\mathrm{P}<0,001)$. Kandungan protein $C$. vulgaris tertinggi didapatkan pada konsentrasi $15 \%$ POC EG yaitu 4,4\% bila dibandingkan dengan konsentrasi 20\% POC EG yaitu $3,4 \%$. Penelitian ini menyimpulkan bahwa konsentrasi $15 \%$ POC EG dapat digunakan sebagai alternatif pupuk organik dalam kultivasi C. vulgaris.
\end{abstract}

Kata Kunci : Chlorella vulgaris, media organik, pertumbuhan, protein.

\section{ABSTRACT}

This study aims to determine the effect of organic media from water hyacinth concentration on growth and protein content of C. vulgaris. This study used a Completely Randomized Design consisting of 5 treatments and 3 replications. The volume of culture media was $300 \mathrm{ml}$ using f/2 media and 5, 10, 15 and $20 \%$ of organic media, with initial stock $10 \times 10^{4} \mathrm{sel} / \mathrm{ml}$. The parameters observed in this study were cell density, cell division rate, specific growth, yield and protein content of $C$. vulgaris. Result of this highest cell density of $C$. vulgaris on the 4th day, the was obtained at $15 \%$ POC EG treatment which was $10.62 \times 10^{5}$ cells $/ \mathrm{ml}$ when compared to the $\mathrm{f} / 2$ medium which was $4.66 \times 10^{5}$ cells $/ \mathrm{ml}$. The highest specific growth at $15 \%$ POC EG treatment was 0.95 days $^{-1}$ when compared to the $\mathrm{f} / 2$ medium which was 0.20 /days. The highest rate of cell division treatment of $15 \%$ POC EG treatment was 1.37 time when compared to the f/2 medium which was 0,29 time. On the 4th day, the highest cell density of $C$. vulgaris was obtained at $15 \%$ POC EG treatment which was $5.81 \times 10^{5}$ cells $/ \mathrm{ml}$ when compared to the $\mathrm{f} / 2$ medium which was $3.33 \times 10^{5}$ cells $/ \mathrm{ml}$. The highest $C$. vulgaris protein content was obtained at a concentration of $15 \%$ POC EG which was $4.4 \%$ when compared with a concentration of $20 \%$ POC EG which was $3.4 \%$. This study concluded that the $15 \%$ POC EG concentration or below could be used as an alternative organic fertilizer in the cultivation of C. vulgaris to obtain better growth and protein content.

Keywords : Chlorella vulgaris, organic media, cell growth, protein.

\section{PENDAHULUAN}

Mikroalga merupakan salah satu mikroorganisme perairan yang potensial untuk dikembangkan, karena mikroalga ini memiliki banyak manfaat contohnya sebagai kebutuhan pakan pada organisme budidaya. Salah satu jenis pakan alami yang dapat digunakan sebagai kebutuhan pakan budidaya adalah jenis mikroalga Chlorella vulgaris (Iba et al., 2014). Beberapa faktor yang perlu diperhatikan dalam pemilihan pakan alami adalah ukuran yang sesuai dengan bukaan mulut larva,mudah dicerna tidak beracun dan mudah dikultur secara massal (Permata dan Manan, 2012).

Kandungan protein mikroalga bervariasi antara spesies dan berkisar dari $12-35 \%$, dan nilai ini dipengaruhi oleh media kultur. Secara umum, mikroalga bisa dianggap sebagai kandidat yang baik untuk budidaya udang jika mengandung protein lebih besar dari $25 \%$ berat 
keringnya (Iba et al., 2014). Saat ini mikroalga khususnya $C$. vulgaris telah banyak digunakan terutama sebagai pakan alami dalam pembenihan ikan, udang dan kerang karena memiliki kandungan nutrisi yang tinggi. $C$. vulgaris mengandung protein sekitar $51-58 \%$ (Umbu $d k k ., 2014)$.

Pembudidayaan $C$. vulgaris dapat dilakukan untuk memenuhi kebutuhan pakan alami terhadap akuakultur. Pertumbuhan $C$. vulgaris sangat dipengaruhi oleh beberapa faktor salah satunya adalah media kultur. Beberapa media kultur yang biasa dipakai untuk budidaya C. vulgaris yaitu media Walne, Guillard's f/2 dan Erdscheiber yang umumnya berupa media anorganik, yang dalam penyediaannya diperlukan biaya yang sangat besar (Chilmawati, 2008). Oleh karena itu, perlu dicari alternatif media kultur yang murah dan memiliki kandungan nutrien yang dapat memicu pertumbuhan mikroalga, salah satunya adalah pupuk organik cair. Pupuk organik cair eceng gondok (POC EG) merupakan hasil fermentasi dari tumbuhan eceng gondok yang melibatkan aktivitas mikroorganisme. Eceng gondok (Eichhornia crassipes) merupakan tumbuhan yang laju pertumbuhannya sangat cepat, tumbuhan air ini dianggap sebagai gulma air karena menyebabkan banyak kerugian. Tetapi disisi lain, eceng gondok (E.crassipes) potensinya sebagai sumber bahan pupuk organik alternatif yang dapat memiliki unsur hara yang tinggi. Eceng gondok dapat dimanfaatkan sebagai pupuk organik karena mengandung unsur $\mathrm{N}$ dan $\mathrm{P}$ (Govere et al., 2016). Pupuk organik cair eceng gondok dengan kandungan sebesar $\mathrm{N}(0,67 \mathrm{ppm})$ dan $\mathrm{P}(190,143 \mathrm{ppm})$ dapat dijadikan sebagai media kultur yang meningkatkan pertumbuhan sel C.vulgaris (Goa $d k k$., 2019). Penelitian mengenai penggunaan pupuk organik cair dari eceng gondok sebelumnya sudah digunakan pada bidang pertanian untuk mengetahui pengaruh pemberian pupuk organik terhadap tinggi, berat basah, berat kering dan jumlah daun tanaman sawi dengan kandungan unsur $\mathrm{N}(0,28 \%)$ dan $\mathrm{P}$ ( 0,0011\%) (Moia $d k k ., 2015)$.

Didalam budidaya $C$. vulgaris pupuk organik eceng gondok diduga akan meningkatkan produktivitas kultur dan mampu menghasilkan protein yang optimal untuk pakan budidaya perairan. Namun demikian belum diketahui konsentrasi POC yang tepat yang dibutuhkan oleh $C$. vulgaris agar dapat memberikan pertumbuhan serta kandungan protein yang baik. Oleh karena itu, maka perlu dilakukan penelitan untuk mengetahui pengaruh konsentrasi pupuk organik cair dari eceng gondok yang berbeda terhadap pertumbuhan dan kandungan protein $C$. vulgaris

\section{BAHAN DAN METODE}

\section{Persiapan POC Eceng gondok}

Pembuatan POC eceng gondok dibuat mengikuti prosedur penelitian yang telah dilakukan Hadisuwito 2012 dalam Moia $d k k$., 2015 yaitu eceng gondok yang dicacah atau dipotong-potong sampai halus. Kemudian menimbang eceng gondok sebanyak $5 \mathrm{~kg}$. Menyiapkan larutan EM4 dan spayer bervolume $1 \mathrm{~L}$ dan diisi dengan air, sebaiknya digunakan air sumur karena tidak mengandung kaporit. EM4 dituangkan ke dalam spayer dengan perbandingan $1 \mathrm{~L}$ air dicampurkan sebanyak 1-2 tutup botol aqua. Kemudian larutan dikocok sampai merata. Eceng gondok yang telah dipotong halus disemprot dengan larutan EM4 hingga merata ke seluruh bagian, kemudian dituangkan ke dalam komposter dan ditutup rapat. Awal pemakaian akan menghasilkan lindi atau pupuk cair setelah 4 minggu. Setelah proses fermentasi selesai POC eceng gondok disaring untuk memisahkan sisa eceng gondok yang tidak terurai oleh bakteri menggunakan saringan plastik. Setelah itu, POC eceng gondok disaring kembali menggunakan kertas saring dan kapas, setelah penyaringan POC dimasukan ke dalam erlenmeyer $1000 \mathrm{ml}$ dan disterilkan menggunakan autoclave dengan suhu $121{ }^{\circ} \mathrm{C}$ selama 15-20 menit. POC eceng gondok yang telah disterilkan kemudian dianalisis untuk mengetahui kandungan $N$ dan $P$. Setelah dianalisis dan diketahui kandungan $\mathrm{N}$ dan $\mathrm{P}$ POC eceng gondok bisa digunakan sebagai pupuk.

\section{Persiapan Wadah Kultur}

Persiapan yang dilakukan adalah menyiapkan rak kultur, erlenmeyer $500 \mathrm{ml}$ sebanyak 15 buah, lampu TL 10 dan 28 watt 2 buah. Erlenmeyer yang akan digunakan dibersihkan dan dikeringkan. Setelah kering bagian mulut erlenmeyer dibungkus menggunakan aluminium foil dan disterilkan menggunakan autoclave dengan suhu $121{ }^{\circ} \mathrm{C}$ selama 15-20 menit. Kemudian memasang timer dan mengatur lampu TL 28 dan 10 watt pada rak kultur dan mengukur lux cahaya lampu TL menggunakan alat Lux meter. 


\section{Pembuatan Media Kultur}

Media kultur yang digunakan pada penelitian ini adalah media pupuk organik cair eceng gondok dan media $\mathrm{f} / 2$ sebagai kontrol. Pembuatan media $\mathrm{f} / 2$ dilakuakan berdasarkan rujukan Iba (2016) yaitu dengan mencampurkan $\mathrm{NaNO}_{3}$ dan $\mathrm{NaH}_{2} \mathrm{PO}_{4}$ masing-masing $132 \mu \mathrm{L}$ dan air laut steril sampai mencapai volume 300 $\mathrm{ml}$. Sedangkan media kultur POC Eceng gondok dibuat dengan cara mencampur POC eceng gondok dengan volume berbeda-beda dan air laut steril sampai mencapai volume $300 \mathrm{ml}$. Terdapat 5 perbedaan konsentrasi POC eceng gondok yang digunakan sebagai perlakuan yaitu perlakuan A yaitu 0\% POC eceng gondok dengan penambahan air laut dan media $\mathrm{f} / 2$ sebanyak $300 \mathrm{ml}$, perlakuan B yaitu 5\% POC eceng gondok ( $15 \mathrm{ml}$ POC eceng gondok +285 $\mathrm{ml}$ air laut steril), perlakuan C yaitu $10 \%$ POC eceng gondok ( $30 \mathrm{ml}$ POC eceng gondok +270 $\mathrm{ml}$ air laut steril), perlakuan D yaitu $15 \%$ POC eceng gondok ( $45 \mathrm{ml}$ POC eceng gondok +255 $\mathrm{ml}$ air laut steril) dan perlakuan E yaitu $20 \%$ POC eceng gondok (60 $\mathrm{ml}$ POC eceng gondok + $240 \mathrm{ml}$ air laut steril).

\section{Persiapan Inokulan Mikroalga Chlorella vulgaris}

Bibit mikroalga $C$. vulgaris berasal dari Balai Perikanan Budidaya Air Payau, Desa Mappakalompo, Kecamatan Galesong, Kabupaten Takalar, Sulawesi Selatan. Bibit mikroalga $C$. vulgaris yang telah disiapkan kemudian dihitung kepadatan sel awal sebelum dikultur. Penghitungan jumlah atau kepadatan sel calon bibit (inokulan) dilakukan dengan menggunakan haemacytometer mengacu pada Fitriani $d k k$., (2017), kepadatan awal bibit $C$. vulgaris yang digunakan yaitu $10 \times 10^{4} \mathrm{sel} / \mathrm{ml}$. Kepadatan awal bibit $C$. vulgaris dihitung menggunakan rumus pengenceran.

$$
\text { V1. } \mathrm{C} 1=\mathrm{V} 2 . \mathrm{C} 2
$$

Dengan: V1 = Volume media dari stok kultur, $\mathrm{C} 1=$ Kepadatan sel stok kultur, V2 = Volume media kultur yang diinginkan, dan $\mathrm{C} 2=$ Kepadatan sel awal yang diinginkan.

\section{Parameter yang Diamati}

\section{Kepadatan Sel}

Penghitungan jumlah sel untuk mendapatkan data kepadatan sel dilakukan sejak inokulasi sampai fase stasioner akhir. Penghitungan jumlah sel dilakukan mulai dari awal (hari ke-0) sampai akhir penelitian (hari ke-
8), pengamatan setiap 2 hari sekali. Jumlah sel dihitung dengan menggunakan haemocytometer yang diletakkan di bawah lensa objektif mikroskop dengan pembesaran 10 kali. Penentuan jumlah mikroalga $C$. vulgaris diketahui dengan cara menghitung banyaknya jumlah sel $C$. vulgaris yang terdapat dalam 9 kotak besar yang berukuran sisi 1 milimeter pada haemocytometer. Kepadatan sel dalam $1 \mathrm{ml}$ sampel dihitung menggunakan rumus Moheimani et al., (2012).

$$
\text { Kepadatan sel }\left(\mathrm{sel} / \mathrm{ml}^{-1}\right)=\frac{\text { Jumlah sel yang dihitung }}{\text { Jumlah } \text { kotak yang dihitung }} \times 10^{4}
$$

\section{Laju Pembelahan Sel $C$. vulgaris}

Laju pembelahan sel $C$. vulgaris dihitung menggunakan rumus dikemukakan Wood et al., (2005).

$$
\mathrm{K}=\frac{1}{\ln 2}\left[\frac{\ln \left(\frac{\mathrm{N}_{1}}{\mathrm{~N}_{0}}\right)}{\left(\mathrm{t}_{1}-\mathrm{t}_{0}\right)}\right]
$$

Dengan: $\mathrm{K}=$ Laju pembelahan sel (perhari), $\mathrm{N} 1=$ Kepadatan sel pada waktu eksponensial, N0 = Kepadatan sel awal, $\mathrm{t} 0=$ waktu awal kultivasi, dan $\mathrm{t} 1$ = waktu pengamatan pada fase eksponensial.

\section{SGR $C$. vulgaris}

SGR C. vulgaris dihitung menggunakan rumus yang dikemukakan oleh Moheimani et al., (2012).

$$
\mathrm{SGR}=\frac{\mathrm{Ln}(\mathrm{N} 1 / \mathrm{N} 0)}{\mathrm{t} 1-\mathrm{t} 0}
$$

Dengan : $S G R=$ Laju pertumbuhan spesifik (perhari), $\mathrm{N} 1$ = Kepadatan sel pada waktu eksponensial, $\mathrm{N} 0=$ Kepadatan sel awal, $\mathrm{t} 0=$ waktu awal kultivasi, dan $\mathrm{t} 1$ = waktu pengamatan pada fase eksponensial.

\section{Yield Chlorella vulgaris}

Yield mikroalga $C$. vulgaris pada penelitian ini dihitung menggunakan rumus Iba et al., (2018).

Yield $(\mathrm{sel} / \mathrm{ml})=\frac{\text { kepadatan sel } \mathrm{N} 1+\text { kepadatan sel N2 }}{2}$

Dengan : $\mathrm{N}_{1}=$ Kepadatan sel awal, $\mathrm{N}_{2}=$ Kepadatan sel akhir.

\section{Kandungan Protein $C$. vulgaris}

C. vulgaris dipanen pada hari ke- 8 kemudian dilakukan sentrifugasi dan dikering anginkan selama 5 menit dengan kecepatan 3000 rpm. Setelah disentrifugasi $C$. vulgaris diuji kandungan protein menggunakan metode kjeldahl. Kandungan protein mikroalga $C$. vulgaris pada penelitian ini dapat dihitung menggunakan rumus AOAC (2005). 


$$
\text { Kadar protein }=\frac{(\mathrm{V} 1-\mathrm{V} 2) \times \mathrm{N} \times 0,014}{\mathrm{~W}} \times 100 \%
$$

Dengan : $\mathrm{W}=$ Bobot, $\mathrm{V}_{1}=$ Volume $\mathrm{HCl} \mathrm{N}$ yang dipergunakan pada penitaran contoh, $\mathrm{V}_{2}=$ Volume $\mathrm{HCl} \mathrm{N}$ yang dipergunakan pada penitaran blanko, $\mathrm{N}$ $=$ Normalitas.

\section{Analisis Data}

Data kepadatan sel dan yield $C$. vulgaris yang dikultur menggunakan konsentrasi pupuk organik cair eceng gondok yang berbeda akan dianalisis menggunakan repeated measures ANOVA. Sedangkan untuk melihat perbedaan SGR dan laju pembelahan sel antar perlakuan dianalisis menggunakan one way analysis of variance (one way ANOVA) pada taraf kepercayaan 95\%. Jika hasil berbeda nyata $(\mathrm{p}<0,05)$ maka dilanjutkan dengan uji Duncan dengan bantuan aplikasi SPSS versi 16.0. Sedangkan untuk penyajian grafik menggunakan Microsoft Exel 2007.

\section{HASIL}

\section{Analisis POC Eceng Gondok}

Hasil analisis N dan P POC eceng gondok yang telah di fermentasikan selama 4 minggu disajikan pada Tabel 1.

\section{Pertumbuhan Mikroalga $C$. vulgaris}

Kepadatan sel mikroalga $C$. vulgaris yang dikultur selama 8 hari disajikan pada Gambar 1 . Kepadatan sel C. vulgaris tertinggi yaitu hari ke4 pada perlakuan $15 \%$ POC EG dengan nilai rata-rata $10,62 \times 10^{5} \mathrm{sel} / \mathrm{ml}$ bila dibandingkan dengan media $\mathrm{f} / 2$ memiliki nilai rata-rata $4,66 \times 10^{5} \mathrm{sel} / \mathrm{ml}$.

Hasil kepadatan sel C. vulgaris menggunakan analisa Repeated Measure ANOVA menunjukkan bahwa selama pengamatan berpengaruh signifikan terhadap pertumbuhan sel $C$. vulgaris $(\mathrm{P}<0,001)$. Sedangkan uji Duncan menunjukkan bahwa konsentrasi $15 \%$ POC EG berbeda nyata sedangakan media f/2, 5\%, $10 \%$ dan 20\% POC EG tidak berbeda nyata.

\section{SGR dan Laju Pembelahan Sel $C$. vulgaris}

$S G R$ sel tertinggi yaitu pada perlakuan $15 \%$ POC EG dengan nilai rata-rata $0,95 \mathrm{sel} / \mathrm{hari}$ bila dibandingkan dengan media $\mathrm{f} / 2$ yaitu 0,20 sel/hari. Sedangkan laju pembelahan sel tertinggi yaitu pada perlakuan 15\% POC EG dengan nilai rata-rata yaitu 1,37 kali bila dibandingkan dengan media f/2 yaitu 0,29 kali. Hasil $S G R$ dan jumlah pembelahan sel $C$. vulgaris menggunakan analisis one way analysis of variance (one way ANOVA) menunjukkan bahwa konsentrasi POC eceng gondok yang berbeda, memberikan pengaruh signifikan $(\mathrm{P}<0,001)$. Sedangkan uji Duncan menunjukkan bahwa konsentrasi media $\mathrm{f} / 2,10 \%$ dan $15 \%$ POC EG, berbeda nyata sedangakan $5 \%$ dan $20 \%$ POC EG tidak berbeda nyata.

\section{Yield C. vulgaris}

Yield tertinggi yaitu hari ke-4 pada perlakuan $15 \%$ POC EG dengan nilai rata-rata $5,81 \times 10^{5} \mathrm{sel} / \mathrm{ml}$ bila dibandingkan dengan media $\mathrm{f} / 2$ yaitu $3,33 \times 10^{5} \mathrm{sel} / \mathrm{ml}$. Hasil yield C. vulgaris menggunakan analisis Repeated Measure ANOVA menunjukkan bahwa konsentrasi POC eceng gondok yang berbeda memberikan pengaruh yang signifikan $(\mathrm{P}<0,001)$. Sedangkan uji Duncan menunjukkan bahwa konsentrasi media $\mathrm{f} / 2,10 \%$ dan $15 \%$ POC EG, berbeda nyata sedangakan 5\% dan 20\% POC EG tidak berbeda nyata.

\section{Kandungan protein $C$. vulgaris}

Histogram kandungan protein mikroalga C. vulgaris yang dianalisis selama 7 hari disajikan pada Gambar 5. Dimana pada perlakuan mengandung protein dengan jumlah sekitar 2,7\%-4,4\%.

Tabel 1. Hasil Analisa Kandungan N dan P POC Eceng Gondok (ppm)

\begin{tabular}{|c|c|c|}
\hline No. & Parameter & Hasil analisis \\
\hline 1. & Phosphat & 192.286 \\
\hline 2. & Nitrogen & 5100 \\
\hline
\end{tabular}

Tabel 2. Hasil Analisa Kandungan N dan P POC Eceng Gondok dalam 300 ml (ppm)

\begin{tabular}{|c|c|c|c|c|c|}
\hline \multirow{2}{*}{ No } & \multirow{2}{*}{ Parameter } & \multicolumn{4}{|c|}{ Konsentrasi dalam $300 \mathrm{ml}$} \\
\hline & & $5 \%$ & $10 \%$ & $15 \%$ & $20 \%$ \\
\hline 1. & Nitrogen & 255 & 510 & 765 & 1.020 \\
\hline 2. & Phosfat & 9,6 & 19,2 & 28,8 & 38,45 \\
\hline
\end{tabular}




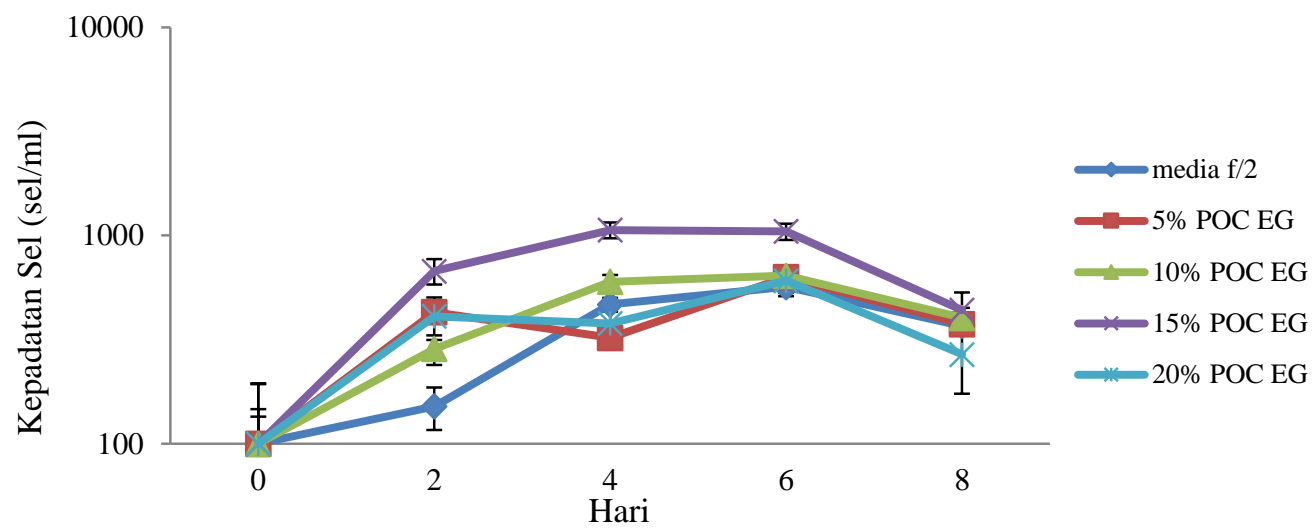

Gambar 1. Grafik pertumbuhan sel C. vulgaris (rata-rata kepadatan jumlah sel $\pm \mathrm{SE}$ )

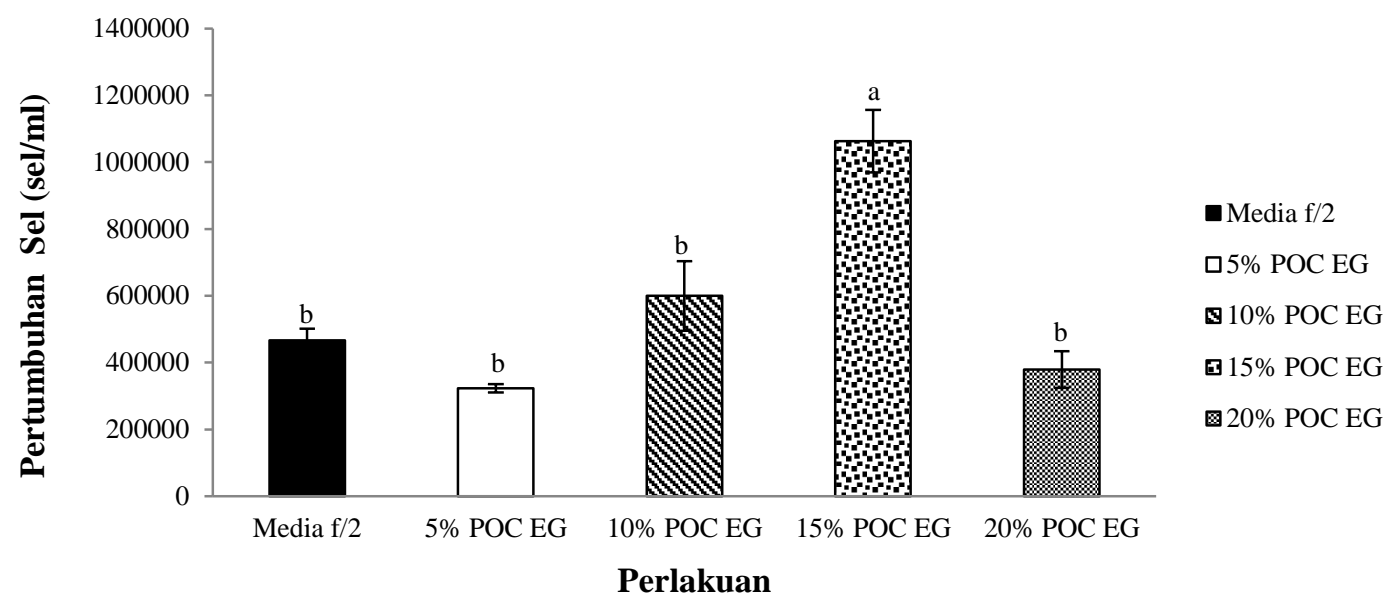

Gambar 2. Histogram pertumbuhan sel pada hari ke-4. ${ }^{\mathrm{a}, \mathrm{b}}$ superscript yang berbeda menunjukkan perbedaan signifikan pada taraf $\alpha=0,05$

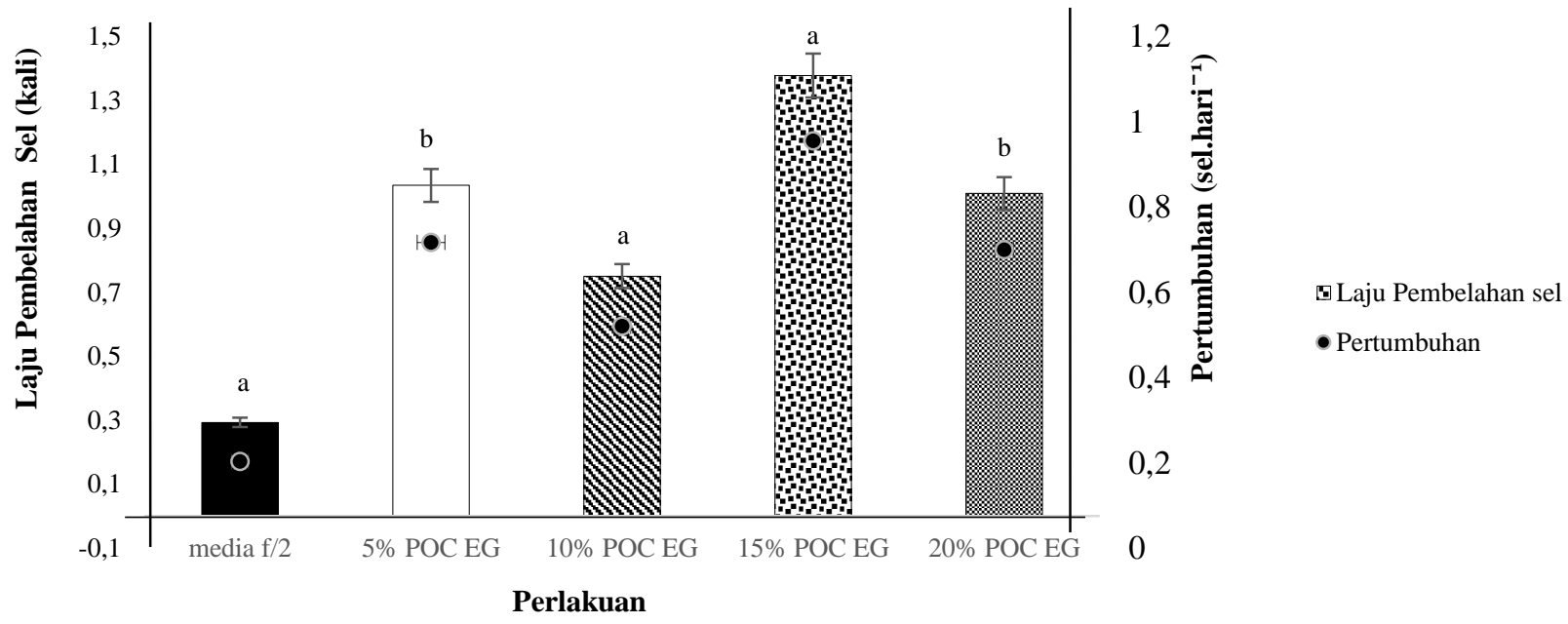

Gambar 3. Histogram Kombinasi $S G R$ dan laju pembelahan sel C. vulgaris (rata-rata jumlah sel $\pm \mathrm{SE}$ ). ${ }^{\mathrm{a}, \mathrm{b}}$ superscript yang berbeda menunjukkan perbedaan signifikan pada taraf $\alpha=0,05$ 


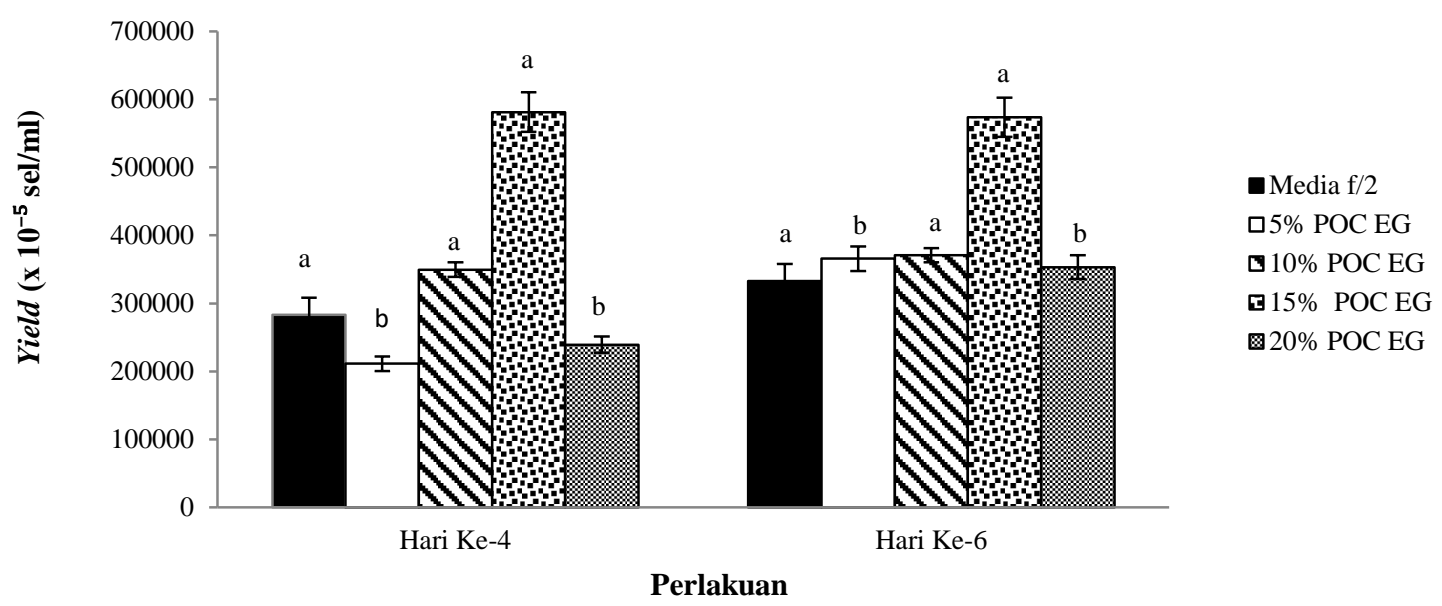

Gambar 4. Histogram yield C. vulgaris (rata- rata jumlah sel $\pm \mathrm{SE}$ ). ${ }^{\mathrm{a}, \mathrm{b}}$ superscript yang berbeda menunjukkan perbedaan signifikan pada taraf $\alpha=0,05$

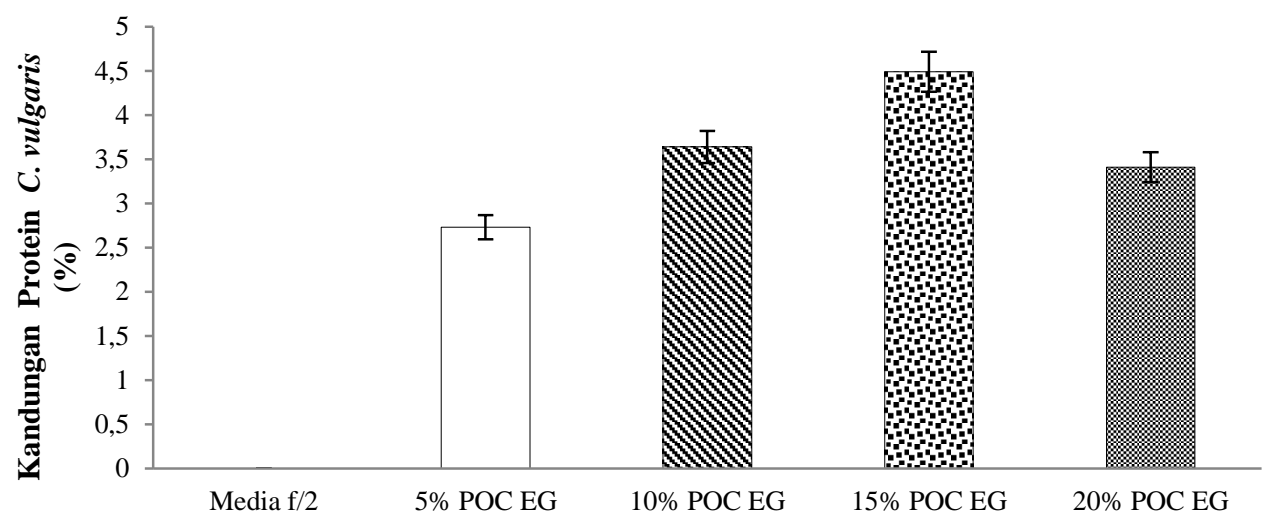

Perlakuan

Gambar 5. Histogram Kandungan protein C. vulgaris

\section{PEMBAHASAN}

Pertumbuhan sel $C$. vulgaris yang dikultur dapat dipengaruhi oleh konsentrasi POC eceng gondok. Kepadatan sel awal inokulan $C$. vulgaris adalah $10 \times 10^{4} \mathrm{sel} / \mathrm{ml}$ meningkat hingga mencapai kepadatan sel tertinggi pada hari ke-4 yaitu pada perlakuan $15 \%$ POC EG dengan nilai rata-rata $10,62 \times 10^{5} \mathrm{sel} / \mathrm{ml}$ bila dibandingkan dengan media f/2 yaitu $4,66 \times 10^{5} \mathrm{sel} / \mathrm{ml}$. Penelitian ini menunjukkan bahwa konsentrasi nutrien terutama $\mathrm{N}$ dan $\mathrm{P}$ dalam media kultur organik (Tabel 1) dan media $\mathrm{f} / 2$ memberikan pengaruh yang berbeda terdapat pertumbuhan $C$. vulgaris. Pertumbuhan pada semua konsentrasi dan $\mathrm{f} / 2$ mencapai fase logaritmik pada hari ke-0 hingga hari ke-2 dan mulai memasuki fase stasioner pada hari ke-4. Kultur mikroalga dalam penelitian ini semua perlakuan mendapatkan intensitas cahaya yang sama yaitu 556 lux (10.564 $\mu \mathrm{mol}$ photons $\left.\mathrm{m}^{2} / \mathrm{s}\right)$, dimana sumber cahaya menggunakan dua lampu TL 28 dan 10 watt. Hal ini sesuai dengan pernyataan Choochote dkk., (2010), C. vulgaris dapat tumbuh dalam keadaan maksimum pada kondisi intensitas cahaya 5.000 lux. Hasil penelitian Wijanarko et al. (2007), biomassa maksimum $C$. vulgaris (Beijerinck) antara 0,1 dan 2,05 g/l ketika kultur diberi pencahayaan 62,5 $\mu \mathrm{mol}$ photons $\mathrm{m}^{2} / \mathrm{s}$ selama 12:12 jam penyinaran terang/gelap. Menurut Biolita dan Harmadi (2017), apabila cahaya yang terserap oleh Chlorella sp. berkurang maka akan menyebabkan laju fotosintesis berjalan lambat, sehingga mengakibatkan pertumbuhan sel menurun.

Hasil pada penelitian ini lebih tinggi dari hasil penelitian yang dilakukan oleh Waney 
(2017), yang menggunakan pupuk eceng gondok dalam kultur $C$. vulgaris selama 14 hari memiliki kepadatan sel yaitu $3,6 \times 10^{5} \mathrm{sel} / \mathrm{ml}$ dengan laju pertumbuhan sel yaitu 0,0020/hari. Kandungan unsur hara $\mathrm{N}$ dalam POC EG pada penelitian ini adalah sebesar 5100 ppm (Tabel 1) pertumbuhan $C$. vulgaris pada penelitian ini masih dalam kondisi optimum sehingga kepadatan sel masing-masing perlakuan diberikan dengan konsentrasi berbeda memiliki pertumbuhan yang lebih baik bila dibandingkan dengan media $f / 2$. Hal ini sebanding dengan Soampa (2016), kisaran nitrat untuk pertumbuhan sel $C$. vulgaris yaitu 0,1-3 ppm. Menurut Rostini (2007), Chlorella sp. tumbuh pada salinitas 25-35 ppt, sementara salinitas 15 ppm tumbuh lambat dan tidak tumbuh pada salinitas 0 ppt dan 60 ppt.

Kandungan unsur hara konsentrasi POC eceng gondok diperoleh unsur P sebesar 192,286 ppm (Tabel 1). Kadar unsur P melebihi batas optimal untuk pertumbuhan sel $C$. vulgaris sehingga perlakuan konsentrasi POC eceng gondok yang lebih banyak menunjukkan pertumbuhan sel $C$. vulgaris lebih lambat dari perlakuan yang diberi konsentrasi POC eceng gondok dengan konsentrasi yang lebih sedikit. Berdasarkan nilai rata-rata kepadatan sel pada perlakuan media f/2 tanpa konsentrasi POC EG memiliki kepadatan sel lebih rendah yaitu 4,66x $0^{5} \mathrm{sel} / \mathrm{ml}$. Kandungan P POC eceng gondok dalam penelitian ini lebih tinggi dibandingkan dengan kandungan P POC eceng gondok hasil penelitian Govere et al., (2016), yaitu sebesar 28,6 ppm.

SGR sel tertinggi pada perlakuan $15 \%$ POC EG dengan nilai rata-rata $0,95 /$ hari bila dibandingkan dengan media $\mathrm{f} / 2$ yaitu 0,20 /hari. Sedangkan laju pembelahan sel per hari tertinggi pada perlakuan $15 \%$ POC EG dengan nilai ratarata yaitu 1,37 kali bila dibandingkan dengan media $f / 2$ yaitu 0,29 kali. Ketersediaan nutrien dalam media kultur yang diberi POC EG dan media $\mathrm{f} / 2$ hampir sama mengandung unsur hara makro dan unsur hara mikro yang dibutuhkan untuk pertumbuhan $C$. vulgaris. Hal ini sesuai dengan pernyataan Syawal (2010), eceng gondok dimanfatkan sebagai pupuk organik karena mengandung $\mathrm{N}, \mathrm{P}$ dan $\mathrm{K}$. Menurut Chilmawati (2008), unsur-unsur yang terkandung dalam media Guillard's f/2 memiliki komposisi yang lebih kompleks sehingga sel Chlorella sp. dapat tumbuh dengan cepat. POC EG dapat digunakan sebagai alternatif pengganti pupuk anorganik komersial media $\mathrm{f} / 2$ yang relatif lebih mahal dalam kultivasi $C$. vulgaris. Hal ini disebabkan oleh tersediaan nutrien dalam media kultur yang diberi POC eceng gondok dan media f/2 hampir sama mengandung unsur hara makro dan mikro yang dibutuhkan oleh pertumbuhan $C$. vulgaris. Hal ini sebanding dengan pernyataan Regista (2017), selain unsur hara kepadatan sel juga dipengaruhi oleh temperatur, salinitas, cahaya, dan $\mathrm{pH}$. Semua faktor tersebut harus berada dalam kondisi optimum untuk pertumbuhan mikroalga agar produk sel dan bahan metabolit berada dalam keadaan maksimum.

Yield tertinggi yaitu hari ke-4 pada perlakuan 15\% POC EG dengan nilai rata-rata $5,81 \times 10^{5} \mathrm{sel} / \mathrm{ml}$ bila dibandingkan dengan media $\mathrm{f} / 2$ yaitu $3,33 \times 10^{5} \mathrm{sel} / \mathrm{ml}$. Pada hari ke-4 merupakan waktu yang tepat untuk dilakukan pemanenan sel karena pada hari tersebut merupakan fase eksponensial dimana kepadatan sel pada hari tersebut meningkat dari kepadatan sel hari sebelumnya akibat ketersediaan nutrien yang cukup untuk pertumbuhan $C$. vulgaris. Sedangkan pada hari ke- 8 pertumbuhan sel menurun dan banyak sel $C$. vulgaris yang mati akibat berkurangnya nutrien dalam media kultur dan banyaknya akumulasi racun dalam media kultur yang berasal dari hasil metabolisme sel yang tidak terurai. Menurut pernyataan Isnansetyo dan Kurniastutuy (1995), fase kematian ditandai dengan jumlah sel mikroalga yang mati lebih banyak dari jumlah sel yang hidup. Nutrien semakin menipis (bahkan habis), cadangan makanan dalam tubuh sel menjadi berkurang, dan pemupukan racun semakin meningkat. Pada fase ini sel yang mati bahkan dapat lisis (pecah) dan larut kedalam medium.

Kandungan protein $C$. vulgaris memiliki nilai tertinggi pada konsentrasi $15 \%$ POC EG $(4,6 \%)$. Penelitian ini memiliki nilai kandungan protein terendah bila dibandingkan dengan penelitian Wijoseno (2011), C. vulgaris memiliki Kandungan protein yaitu BG-11 $(46,9 \%)$, Beneck $(36,3 \%)$, dan Walne $(36,15 \%)$ dengan media kultur yang digunakan adalah media anorganik. Pada masing-masing perlakuan penelitian ini memiliki konsentrasi nitrogen yang berbeda (Tabel 2), sehingga dapat mempengaruhi kandungan protein mikroalga $C$. vulgaris. Konsentrasi $15 \%$ POC EG memiliki nitrogen yang tepat sehingga dapat mengakumulasi produksi biomassa. Menurut Wijoseno (2011), mikroalga yang tumbuh pada 
kondisi yang cukup akan nitrogen dalam kultur biakan akan cenderung mengakumulasi sejumlah besar produksi biomassa, protein dan asam nukleat. Nitrogen merupakan makronutrisi yang dapat mempengaruhi pertumbuhan mikroalga dalam kegiatan metabolisme sel yaitu kegiatan transpotasi, katabolisme, asimilasi dan khususnya biosintesis protein.

Berdasarkan hasil analisa, C. vulgaris memiliki nilai konsentrasi $\mathrm{N}$ dan $\mathrm{P}$ tertinggi pada perlakuan 20\% POC EG (Tabel 2) tetapi kandungan protein tertinggi menunjukkan pada konsentrasi 15\% POC EG bila dibandingkan dengan 20\% POC EG. Penelitian ini menunjukkan bahwa media organik pada konsentrasi 15\% POC EG adalah pilihan yang baik untuk kultur $C$. vulgaris, memberikan pertumbuhan yang tepat dan kandungan protein tinggi mikroalga.

\section{KESIMPULAN}

Konsentrasi POC eceng gondok 15\% dapat meningkatkan pertumbuhan sel, laju pembelahan sel, SGR, yield dan kandungan protein $C$. vulgaris dengan nilai statistik berbeda dengan media $\mathrm{f} / 2$ sehingga POC eceng gondok dapat digunakan sebagai alternatif pengganti pupuk anorganik komersial media $\mathrm{f} / 2$ dalam kultivasi $C$. vulgaris. Namun demikian, perlu penelitian lebih lanjut untuk menguji konsentrasi POC eceng gondok 15\% atau konsntrasi dibawa POC eceng gondok 5\% dan pemanenan dilakukan pada fase stasioner.

\section{REFERENSI}

AOAC (Association of Official Analytical Chemyst). 2005. Official Method of Analysis of The Association of Offical Analytical of Chemyst. Arlington, Virginial, USA: Published by The Association of Offical Analytical of Chemyst. Inc.

Biolita, N.O., Harmadi. 2017. Perancangan Fotobioreaktor Mikroalga Chlorella vulgaris untuk Mengoptimalkan Kosentrasi Oksigen $\left(\mathrm{O}_{2}\right)$. Jurnal Fisika Unand, 6(3): 296-305. https://doi.org/10.25077/jfu.6.3.296305.2017

Chilmawati, D., Suminto. 2008. Penggunaan Media Kultur yang Berbeda Terhadap Pertumbuhan Chlorella sp. Jurnal Saintek Perikanan, 4(1): 42-49. https://doi.org/10.14710/ijfst.4.1.42-49
Choochote, W., Paiboonsin, K., Ruangpan, S., Phauruang, A., 2010. Effects of Urea and Light Intensity on the Growth of Chlorella sp. The 8th International Symposium on Biocontrol and Biotechnology.

Fitriani, Fendi, Rochmady. 2017. Pengaruh Pemberian Pupuk Anorganik (NPK+Silikat) dengan Dosis Berbeda Terhadap Kepadatan Skeletonema costatum pada Pembenihan Udang Windu. Akuatikisle: Jurnal Akuakultur, Pesisir dan Pulau-pulau Kecil, 1(1): 1118.

https://doi.org/10.29239/j.akuatikisle.1.1. 11-18

Goa, S., Iba, W., Indrayani. 2019. Pengaruh Dosis Pupuk Organik Cair dari Eceng Gondok (Eichhornia crassipes) yang Berbeda terhadap Pertumbuhan Chlorella vulgaris. Jurnal Media Akuatika, 4(2): 6876.

Govere, S., Madziwa, B., Mahlatini, P. 2016. The Nutrient Content of Organic Liquid Fertilizers in Zimbabwe. International Journal of Modern Engineering Research (IJMER), 1(1): 196-202.

Hadisuwito, S. 2012,. Membuat Pupuk Organik Cair. PT. Agro Media Pustaka. Jakarta.

Iba, W., Rice, M, A., Wikfors, G. H. 2014. Microalgae in Eastern Pacific White Shrimp, Litopenaeus vannamei (Boone 1931) Hatcheries: a Review on Roles and Culture Environments. Asian Fisheries Science, 27: 212-233.

Iba, W. 2016. The Potential of Indonesian Microalal Strains to Support (Eastern White Shrimp (Litopenaeus vannamei) Aquacultur. Tesis Doktor, Fakultas Ilmu Biologi dan Lingkungan, Universitas Rhode Island. Amerika Serikat.

Iba W., Rice M.A., Maranda L., Wikfors G.H. 2018. Growth Characteristics of Newly Isolated Indonesian Microalgae Under Different Salinity. Indonesian Aquaculture Journal, 13 (2): 71-81. http://dx.doi.org/10.15578/iaj.13.2.2018. $71-81$

Isnansetyo, A. dan Kurniastuty. 1995. Teknik Kultur Phytoplankon dan Zooplankton. Kanisius. Yogyakarta.

Moheimani, N. R., Borowitzka, M.A., Isdepsky, A., Ing, S. F. 2012. Standard Methods for Measuring Growth of Algae and their 
Composition. Algae for Biouels and Energy, 5(1), 265-284.

Moia, R. A., Pandiangana. D., Siahaana, P., Tangapoa, M., A. 2015. Pengujian Pupuk Organik Cair dari Eceng Gondok (Eichhornia crassipes) Terhadap Pertumbuhan Tanaman Sawi (Brassica juncea). Mipa Unsrat Online, 4(1): 15-19. https://doi.org/10.35799/jm.4.1.2015.689 7

Permata, I. S.,Manan, A. 2012. Pola Petumbuhan Nannochloropsis ocula pada Kultur Skala Laboatorium, Intermediet dan Massal. Ilmiah Perikanan dan Kelautan. 4(2): 123125.

Syawal, Y. 2010. Pertumbuhan Tanaman Lidah Buaya dan Gulma yang Diaplikasikan Bokhasi Eceng Gondok dan Kiambang serta Pupuk Urea, Agrivigor, 10(1): 108116.

Regista, Ambeng, Litaay, M., Ruslan M., U. 2017. Pengaruh Pemberian Vermikompos Cair Lumbricus Rubellus Hoffmeister Pada Pertumbuhan Chlorella sp. Bioma: Jurnal Biologi Makassar, 2(1): 1-8. http://dx.doi.org/10.20956/bioma.v2i1.13 46

Rostini, I. 2007. Kultur Fitoplankton (Chlorella sp. dan Tetraselmis sp.) pada Skala Laboratorium di Instalasi Penelitian dan Pengkajian Teknologi Pertanian Bojonegara. Fakultas Perikanan dan Ilmu Kelautan. Universitas Padjajaran. Bandung.

Umbu, I., J., Ridlo, A., Djunaedi, A. 2014. Kandungan Total Lipid Chlorella vulgaris yang Dikultur dalam Media yang Diinjeksi $\mathrm{CO}_{2}$. Journal Of Marine Research, 3(4): 578-585. https://doi.org/10.14710/jmr.v3i4.11418

Waney, L. 2017. Pengaruh Penambahan Eksrak Eceng Gondok (Eichornia crassipes) terhadap Laju Pertubuhan Pakan Alami Chlorella sp. Skripsi. Fakultas Perikanan dan Ilmu Kelautan Universitas Gorontalo.

Wijanarko, A., Dianursanti., Valentino., Hermansyah, H., Gozan, M., Witarto, A.B., Soemantojo, R.W. 2007. Pengaruh Pencahayaan Siklus Harian terhadap Produksi Biomassa Chlorella vulgaris Buitenzorg dalam Fotobioreaktor Kolom Gelembung. Jurnal Teknologi, 1(1): 5865 .
Wijoseno, T. 2011. Uji Pengaruh Variasi Media Kultur terhadap Tingkat Pertumbuhan dan Kandungan Protein Lipid, Klorofil, dan Karotenoid pada Mikroalga Chlorella vulgaris Buitenzorg. Fakultas Universitas Indonesia.

Wood, A. M., Everroad, AC., and Wingard, L.M., 2005. Measuring growth rates in Microalgae Culture. In: Algat culturing techniques. Academic Press. 